Mochamad Tamim Ma'ruf. 2017. Rekayasa Nilai Harga Pembuatan Terhadap Efektifitas Penggunaan Bahan Pada Pembangunan Perumahan Tirto Penataran Asri Tipe 70/135 Kecamatan Nglegok Kabupaten Blitar. Jurnal Qua Teknika, (2017), 7(1) : 43 52

\title{
REKAYASA NILAI HARGA PEMBUATAN TERHADAP EFEKTIFITAS PENGGUNAAN BAHAN PADA PEMBANGUNAN PERUMAHAN TIRTO PENATARAN ASRI TIPE 70/135 KECAMATAN NGLEGOK KABUPATEN BLITAR
}

\author{
Mochamad Tamim Ma'ruf \\ Universitas Islam Balitar \\ Jl. Majapahit 12A Blitar \\ mtmtamim@gmail.com
}

\begin{abstract}
Abstrak
One-solving methods and techniques necessary to avoid inefficiencies and not economic costs as well as reduce the cost of housing construction is the method of Value Engineering. Value engineering is a method and cost control techniques to analyze a function to its value at the lowest cost alternative (most economical) without reducing the quality desired.

At the writing of this study used a comparison method by comparing the initial design to the design proposal of the author. In the housing projects Upgrading Tirto Penataran Asri type 70, the application of Value Engineering conducted on the job a couple walls and roofs pair by replacing some work items with a more economical alternative but does not change the original function and high aesthetic level and still qualify safe. For that performed the step of determining a work item, the alternative stage, the analysis stage, and the stage of recommendations to get a Value Engineering application and cost savings against the wall a couple of work items and partner roof.

The proposed design as compared to the initial design. Work items discussed was the work of a couple wall having analyzed obtained savings of Rp. 2,747,643.56 and the work of the roof pair obtained savings of Rp. 2,363,446.80. Thus the total overall savings gained is Rp 5,111,090.36 or savings of $0048 \%$.
\end{abstract}

Keywords: Value Engineering Housing Development, Savings

\section{PENDAHULUAN}

Saat ini kebutuhan akan hunian yang layak dan terjangkau masyarakat sangat tinggi. Untuk itu perlu disiasati pembiayaan proyek yang optimal sehingga dapat memberikan keuntungan bagi setiap penyedia perumahan siap huni yang terlibat. Dalam hal ini kontraktor dapat memperoleh keuntungan tanpa mengorbankan kualitas dan fungsi dari proyek tersebut.

Dalam pengendalian pembiayaan dapat dilakukan upaya-upaya agar realisasi biaya yang terjadi sesuai dengan kebutuhan pelaksanaan dan tidak berlebihan, seperti 
upaya penekanan biaya yaitu melakukan penghematan tanpa mengurangi kuantitas maupun kualitas. Oleh karena itu, dalam perencanaan suatu konstruksi harus mempunyai suatu teknik yang memiliki potensi keberhasilan cukup besar dalam mengendalikan biaya yaitu teknik Rekayasa Nilai (Value Enginering) yang bertujuan untuk mengidentifikasi dan menghilangkan biaya-biaya yang tidak perlu tanpa mengorbankan kualitas produk.

Rekayasa Nilai adalah usaha yang terorganisasi secara sistematis dan mengaplikasikan suatu teknik yang telah diakui, yaitu teknik mengidentifikasi fungsi produk atau jasa yang bertujuan memenuhi fungsi yang diperlukan dengan harga yang terendah.

\section{LANDASAN TEORI}

\subsection{Pengertian Value Engineering}

Menurut Dr. Ir. S. Chandra yahun 1987 bahwa Value Engineering Program adalah Proven Management Technique yang menggunakan systematic approach, dan usaha yang terorganisir yang diarahkan untuk menganalisa fungsi dari suatu item atau system dengan tujuan untuk mencapai fungsi yang diperlukan itu dengan biaya yang seringan-ringannya, konsisten dengan ketentuan untuk penampilan, realibilitas, kualitas, dan pemeliharaan dari proyek tersebut. Value Engineering Program dapat mengurangi biaya proyek dengan jalan mengurangi biaya-biaya yang tidak diperlukan yang berhubungan dengan masalah teknik.

\subsection{Unsur-unsur Utama Rekayasa Nilai (VE)}

Rekayasa Nilai (Value Engineering) mempunyai beberapa kemampuan yang dapat dipakai sebagai alat bagi Value Analysis. Kemampuan itu dikenal sebagai unsur-unsur utama dari Value Engineering, adapun unsur-unsur utama tersebut adalah sebagai berikut:

a. Pemilihan proyek-proyek untuk Value Engineering Study.

b. Penentuan harga untuk Value.

c. Biaya Siklus Hidup (The Life Cycle Costing).

d. Fungsional Approach (The Functional Approach).

e. Functional Analysis System Technique (FAST).

f. Rencana Kerja Value Engineering.

g. Kreatifitas.

h. Menetapkan dan mempertahankan Value Engineering.

i. Human Dynamics (kebiasaan, penghalang, dan sikap).

j. Hubungan antara Pemberi Tugas, Konsultan Perencana, dan Konsultan Value Engineering.

Setiap unsur diatas adalah dipergunakan didalam Value Engineering Study atau unsur-unsur tersebut perlu diarahkan didalam memimpin Value Engineering Study untuk suatu proyek. 
Mochamad Tamim Ma'ruf. 2017. Rekayasa Nilai Harga Pembuatan Terhadap Efektifitas

Penggunaan Bahan Pada Pembangunan Perumahan Tirto Penataran Asri Tipe 70/135 Kecamatan Nglegok Kabupaten Blitar. Jurnal Qua Teknika, (2017), 7(1) : 43 52

\subsection{Sebab-sebab Timbulnya Biaya yang Tidak Diperlukan}

Menurut Dr. Ir. S. Chandra timbulnya biaya yang tidak diperlukan atau Nilai Kurang, pada umumnya disebabkan oleh beberapa hal dibawah ini :

1. Kekurangan Waktu

Setiap Perencana mempunyai batas waktu untuk menyerahkan hasil perencanaannya. Apabila ia tidak menyerahkan tepat pada waktunya, maka reputasinya akan terpengaruh. Dalam kata lain, perencana hanya memiliki waktu yang terbatas untuk membuat perbandingan biaya untuk mencapai nilai yang diinginkan.

2. Kekurangan Informasi

Material dan produk-produk baru terus menerus memasuki pasaran, dan tidak mungkin untuk mengetahui semua perubahan-perubahan ini. Demikian pula sulit untuk menerima semua produk yang baru itu sebelum terbukti integritasnya.

3. Kekurangan Ide

Setiap expert mempunyai spesialisasinya masing-masing, tidak ada orang yang dapat menguasai keahlian dalam semua bidang.

\subsection{Waktu Penerapan Value Engineering}

Secara teoritis, program VE diaplikasikan pada setiap saat, sepanjang waktu berlangsungnya proyek itu dari awal hingga selesainya pelaksanaan pembangunan proyek, bahkan sampai pada tahap penggantian (replacement). Seringkali proyek telah berjalan tanpa diadakan value study. Hal yang demikian ini seharusnya tidak terjadi, sehingga penting sekali bagi konsultan VE untuk menjamin dan menyakinkan bahwa setiap proyek akan dapat mencapai penghematan biaya melalui usaha VE. Lebih praktis apabila VE dapat diaplikasikan pada saat tertentu dalam tahap perencanaan untuk mencapai hasil yang maksimal. Waktu adalah penting sekali secara umum dapat dikatakan bahwa program VE harus dimulai sejak tahap konsep dan secara kontinue pada setiap tahap sampai selesai perencanaan.

\subsection{Rencana Kerja Value Engineering (VE)}

Rencana kerja VE merupakan suatu pendekatan yang sistematis dan terorganisir, keberhasilan suatu VE studi tergantung dari keberhasilan rencana kerja tersebut. Selain itu rencana kerja VE merupakan salah satu spesifik metode optimasi biaya dengan teknik VE.

Rencana Kerja VE merupakan suatu studi untuk mengidentifikasi ongkosongkos yang tidak berguna dan mencoba menghilangkan dengan menampilkan ideide baru berkaitan dengan struktur tersebut dengan fungsi yang sama. Rencana kerja VE terdiri dari tahap-tahap yang saling berhubungan satu sama lain yang menjelaskan proses analisa secara gambling dan terpadu.

\subsection{Tahap Informasi}


Mochamad Tamim Ma'ruf. 2017. Rekayasa Nilai Harga Pembuatan Terhadap Efektifitas Penggunaan Bahan Pada Pembangunan Perumahan Tirto Penataran Asri Tipe 70/135 Kecamatan Nglegok Kabupaten Blitar. Jurnal Qua Teknika, (2017), 7(1) : 43 52

Dalam tahap informasi dilakukan pendefinisian proyek, menelusuri informasi latar belakang yang menjadi dasar desain, persyaratan dan batas proyek, dan kepekaan terhadap biaya dari segi kepemilikan dan pengoperasian suatu fasilitas. Makna dari tahap informasi adalah untuk memperoleh sebanyak mungkin informasi dan pengetahuan proyek.

Segala informasi yang diterima baik dari pemilik, perencana, kontraktor, konsultan, badan usaha maupun perorangan dan pemerintah akan dikumpulkan dan segala informasi mengenai data-data teknis proyek.

Tahap informasi dalam Rencana Kerja Value Engineering mencakup tujuan sebagai berikut:

1. Mengumpulkan data yang berkaitan dengan obyek yang ditinjau saat ini

2. Menentukan fungsi dari tujuan tersebut

3. Mengevaluasi fungsi dasarnya

\subsection{Tahap Kreatifitas / Alternatif}

Pada tahap ini kemungkinan lain dianalisa dengan menanyakan apakah ada alternatif lain yang dapat memenuhi fungsi atau kegunaan yang sama. Pada penulisan tugas akhir ini, alternatif yang diusulkan mungkin didapat dengan pengurangan komponen, penyederhanaan, ataupun modifikasi dengan tetap mempertahankan fungsi utama dari obyek. Selama tahap ini usaha kreatif diarahkan menuju pengembangan alternatif untuk menyempurnakan fungsi-fungsi yang dibutuhkan. (Soeharto, $1995: 319$ )

\subsection{Tahap Analisa}

Alternatif-alternatif yang dihasilkan pada tahap kreatifitas diatas akan dibahas lebih lanjut pada tahap analisa. Dalam tahap analisa dilakukan evaluasi terhadap setiap ide yang tertampung pada tahap kreatifitas untuk melihat apakah ide tersebut bisa atau tidak untuk dikembangkan lebih dan direkomendasikan sebagai hasil yang memiliki nilai tambah.

\subsection{Tahap Proposal}

Tahap proposal merupakan proses menggiring ide terbaik diusulkan untuk bisa diterima dan dilaksanakan oleh pemilik. Pada tahap ini, semua data yang dihadirkan oleh pemilik proyek, perencanaan pelaksana dan semua pihak yang terlibat untuk memintakan persetujuan penerapannya pada proyek yang akan dikerjakan. Proposal bisa mengubah desain dan penghematan menjadi salah satu ukuran bahwa usulan tersebut bisa diterima.

\section{METODE PENELITIAN}

\subsection{Definisi}


Metode dalam hal ini adalah tata cara atau jalan yang ditempuh sehubungan dengan penelitian yang dilakukan, yang memiliki langkah-langkah yang sistematis untuk menyelesaikan masalah yang dibahas dengan mendayagunakan sumber data dan fasilitas yang ada. Metode juga merupakan cara kerja untuk dapat memahami hal yang menjadi sasaran penelitian, meliputi prosedur penelitian dan teknik penelitian (Hasan,2002).

\subsection{Proses Penelitian}

Langkah-langkah dan hal-hal yang perlu dilakukan dalam proses penelitian, diantaranya :

1. Tahap Persiapan

Sebelum melakukan proses penelitian, peneliti harus melakukan tahap persiapan, diantaranya mengumpulkan atau mencari data-data proyek. Pencarian data dapat dilakukan baik pada konsultan, kontraktor maupun pada Kementerian Pekerjaan Umum yang menangani proyek-proyek besar.

2. Data Penelitian

Data yang digunakan dalam penelitian dikelompokkan menjadi 2 yaitu Data Primer dan Data Sekunder.

3. Metode Pengumpulan Data

Pengumpulan data dapat dilakukan dengan cara melakukan survey langsung pada konsultan maupun pelaksana yang menangani proyek tersebut dan melakukan survey langsung pada instansi-instansi atau perusahaan-perusahaan yang dianggap berkepentingan.

\subsection{Analisa Data}

Dari data-data yang telah dikumpulkan dilakukan analisis Rekayasa Nilai untuk menghasilkan adanya suatu penghematan biaya atau saving cost. Analisis Rekayasa Nilai dilakukan lima tahap, yaitu :

a. Tahap Informasi

Pada tahap awal ini dilakukan upaya-upaya untuk mendapatkan informasi sebanyak-banyaknya yang relevan dengan obyek studi yang akan dievaluasi, dimana data dan informasi tersebut diolah menurut kebutuhan pada tahap selanjutnya.

b. Tahap Kreatif

Di dalam Rekayasa Nilai, berfikir kreatif adalah hal yang sangat penting dalam mengembangkan ide-ide untuk memunculkan alternatif-alternatif dari elemen yang masih memenuhi fungsi tersebut, kemudian disusun secara sistematis. Alternatif-alternatif tersebut dapat ditinjau dari berbagai aspek, diantaranya :

1) Bahan atau material 
Mochamad Tamim Ma'ruf. 2017. Rekayasa Nilai Harga Pembuatan Terhadap Efektifitas

Penggunaan Bahan Pada Pembangunan Perumahan Tirto Penataran Asri Tipe 70/135 Kecamatan Nglegok Kabupaten Blitar. Jurnal Qua Teknika, (2017), 7(1) : 43 52

Pemunculan penggunaan alternatif bahan dikarenakan semakin banyaknya jenis bahan bangunan yang diproduksi dengan kriteria mempunyai fungsi yang sama. Seiring dengan berkembangnya kemajuan teknologi jenis bahan yang mempunyai fungsi yang sama dapat dibuat atau dicetak dengan mutu dan kualitas yang hampir sama juga. Hanya karena memiliki merek atau lisensi yang berbeda, maka harga bahan tersebut menjadi berbeda. Dengan demikian, maka pemilihan alternatif bahan dapat dilakukan dalam analisis Rekayasa Nilai. Pencarian bahan dengan mutu, kualitas dan fungsi yang sama dengan rencana awal tapi dengan harga lebih rendah dapat dilakukan.

2) Cara atau metode pelaksanaan pekerjaan

Dalam melaksanakan suatu pekerjaan pastinya mempunyai cara atau metode sendiri-sendiri. Pada zaman dahulu cara menyelesaikan suatu pekerjaan hanya mengandalkan tenaga manusia dengan alat-alat sederhana, sehingga waktu penyelesaian pekerjaan dapat membutuhkan waktu yang cukup lama. Seiring dengan kemajuan teknologi, kini muncul alat-alat bantu yang lebih canggih dalam menyelesaikan pekerjaan. Sebagai contoh, adanya alat-alat berat seperti dozer, excavator, crane dan lain-lain yang dapat membantu dalam menyelesaikan pekerjaan konstruksi bangunan, sehingga pekerjaan dapat cepat selesai. Dengan demikian dapat dilihat, bahwa suatu pekerjaan konstruksi bangunan yang dikerjakan dengan tenaga manusia dan alat-alat sederhana akan membutuhkan waktu yang lama dibandingkan dengan dikerjakan menggunakan alat-alat yang lebih modern. Maka dalam analisis Rekayasa Nilai dapat berpedoman pada metode pelaksanaan, karena semakin pendek waktu yang dibutuhkan dalam menyelesaikan pekerjaan dan dengan peralatan yang optimal, maka semakin kecil pula biaya yang dikeluarkan.

3) Waktu pelaksanaan pekerjaan

Setiap pekerjaan dalam suatu proyek pastinya sudah mempunyai jadwal pelaksanaan dalam perencanaan time schedule. Terkadang dengan bobot pekerjaan yang tetap, waktu pelaksanaan pekerjaan dapat dikurangi, asalkan pekerjaan tersebut tidak terdapat dalam jalur kritis. Banyak cara yang dilakukan untuk mewujudkan hal tersebut, diantaranya dengan mengganti metode pelaksanaan, menambah jumlah tenaga kerja dan lain-lain. Dengan demikian, alternatif pengurangan waktu pelaksanaan dapat dijadikan pedoman karena akan berpengaruh pada perhitungan anggaran biaya.

\subsection{Tahap Analisa}

Tujuan tahapan ini adalah : 
Mochamad Tamim Ma'ruf. 2017. Rekayasa Nilai Harga Pembuatan Terhadap Efektifitas

Penggunaan Bahan Pada Pembangunan Perumahan Tirto Penataran Asri Tipe 70/135 Kecamatan Nglegok Kabupaten Blitar. Jurnal Qua Teknika, (2017), 7(1) : 43 52

1. Mengadakan evaluasi, mengajukan kritik dan menguji alternatif yang muncul selama tahapan spekulatif.

2. Memperkirakan nilai uang untuk setiap alternatif.

3. Menentukan alternatif yang akan memberikan kemampuan yang paling besar untuk penghematan biaya.

Alternatif yang timbul diformulasikan, kemudian melakukan eliminasi ide-ide yang kurang praktis dan menilai ide kreatifitas tersebut dari segi keuntungan dan kelemahannya dengan mencari potensi penghematan biaya untuk setiap ide yang dievaluasi.

\subsection{Tahap Rekomendasi}

Mempersiapkan rekomendasi yang telah dilengkapi informasi dan perhitungannya secara tertulis dari alternatif yang dipilih dengan mempertimbangkan pelaksanaan secara teknis dan ekonomis.

Langkah-langkah tahapan rekomendasi adalah sebagai berikut :

Membuat konsep / desain untuk dibandingkan satu sama lain.

Membandingkan konsep semula dengan desain usulan / alternatif.

Dalam tahap rekomendasi dapat juga berisi usulan alternatif yang direkomendasikan beserta dasar pertimbangan.

\subsection{Bagan Alir Proses Penelitian}

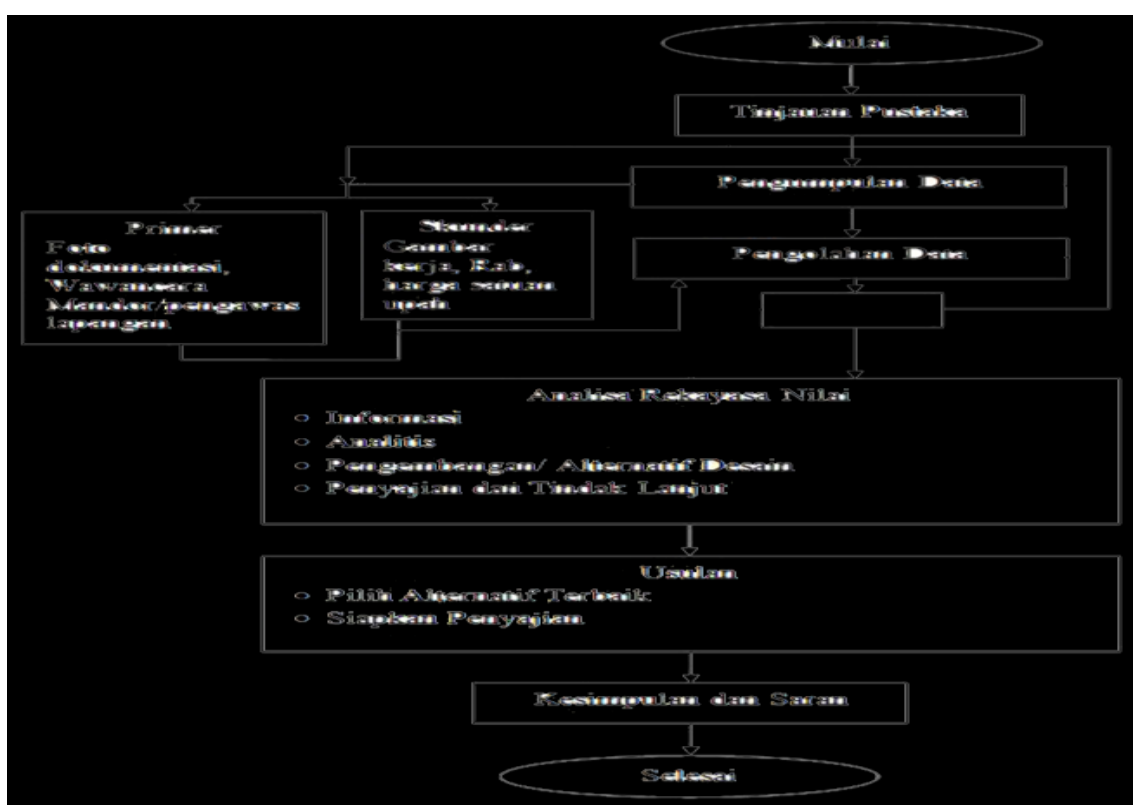

4 HASIL DAN PEMBAHASAN

4.1. Identifikasi Biaya Tinggi 
Mochamad Tamim Ma'ruf. 2017. Rekayasa Nilai Harga Pembuatan Terhadap Efektifitas

Penggunaan Bahan Pada Pembangunan Perumahan Tirto Penataran Asri Tipe 70/135 Kecamatan Nglegok Kabupaten Blitar. Jurnal Qua Teknika, (2017), 7(1) : 43 52

Identifikasi biaya tinggi dilakukan dengan cara break down biaya, yaitu dengan menempatkan biaya pekerjaan secara urut mulai dari nominal terbesar sampai dengan kecil. Dengan menganalisa Rencana Anggaran Biaya Pembangunan rumah tinggal type 70 dan didapati item pekerjaan pasangan memiliki biaya tinggi yaitu sebesar Rp. 33,482,047.37,- dan pekerjaan atap memiliki biaya sebesar Rp. $20,179,567.70$,- yang pada item ini memiliki biaya paling tinggi.

\subsubsection{Pemilihan Item Pekerjaan}

Berdasarkan hasil identifikasi biaya tinggi di tas didapati bahwa pekerjaan pasangan, pekerjaan atap dan pekerjaan beton. Oleh karena itu pekerjaan yang akan dianalisa Rekayasa Nilai adalah pekerjaan tersebut. Sehingga dengan cara ini dapat menekan biaya proyek secara keseluruhan, sekaligus dapat menghemat bahan serta biaya pemasangan dan tidak mengubah fungsi suatu bangunan.

\subsection{Tahap Alternatif}

Dalam analisa proyek pembangunan rumah tinggal yang dikerjakan disini digunakan metode Brainstroming yaitu teknik merangsang anggota tim untuk menjajaki alternatif yang mungkin biasa dipakai untuk menyelasaikan masalah secara bebas tanpa adanya kritik atas ide - ide yang diajukan. Untuk pengumpulan alternatif desain dan tidak perlu kita pertimbangkan faktor kriteria, keindahan, harga spesifikasi maupun batasan desain yang ada serta pertimbangan lainya.

\subsection{Tahap Rekomendasi}

\subsubsection{Pasangan Dinding}

Dinding mempunyai fungsi dasar membatasi ruangan dan unsur keindahan serta nyaman dan dapat tahan air. Desain awal untuk dinding adalah pasangan bata merah dan dilapisi dengan pasangan keramik 20/25 untuk kamar mandi dan bak, dan dilapisi dengan plesteran dan acian dan mendapat alternatif menjadi Pasangan Batako dan plesteran, acian dan pas keramik 20/20 kamar mandi dan bak.

\subsubsection{Pasangan Atap}

Item pekerjaan atap mempunyai fungsi utama melindungi bangunan. Desain awal dari atap adalah genting beton, rangka baja ringan, List Gypsum, bubungan beton, plafond woodplank menggunakan list dan mendapat alternatif Genting tanah liat karang pilang, reng / usuk meranti, kuda-kuda meranti, listplank meranti, bubungan karang pilang, plafond triplek menggunakan list.

\subsection{Kesimpulan}

Dari hasil analisa yang sudah dilakukan dalam penerapan Rekayasa Nilai pada Proyek Pembangunan Perumahan Tirto Penataran Asri, serta perencanaan desain alternatif dengan berdasar pada Rencana Kerja Rekayasa Nilai, maka dapat diambil beberapa kesimpulan di bawah ini : 
Mochamad Tamim Ma'ruf. 2017. Rekayasa Nilai Harga Pembuatan Terhadap Efektifitas

Penggunaan Bahan Pada Pembangunan Perumahan Tirto Penataran Asri Tipe 70/135 Kecamatan Nglegok Kabupaten Blitar. Jurnal Qua Teknika, (2017), 7(1) : 43 52

1. Rekayasa Nilai pada proyek Perumahan Tirto Penataran Asri Kabupaten dapat diterapkan pada pekerjaan berikut :

a. Pekerjaan pasangan dinding, pada desain awal untuk dinding adalah pasangan bata merah dan dilapisi dengan pasangan keramik 20/25 untuk kamar mandi dan bak, dan dilapisi dengan plesteran dan acian. Setelah dilakukan Rekayasa Nilai maka pasangan diganti menggunakan pasangan batako dan plesteran, acian dan pas keramik 20/20 kamar mandi dan bak tanpa merubah fungsi awal dari item pekerjaan tersebut. Biaya desain awal pada pekerjaan ini sebesar Rp 33,482,047.37 kemudian setelah dilakukan Rekayasa nilai menjadi Rp 30,734,403.81 jadi memperoleh penghematan biaya sebesar Rp.2,747,643.56 untuk pekerjaan pasangan dinding ini.

b. Pada pekerjaan atap dilakukan perubahan pada genteng, genteng bubungan dan plafond. Pada Desain awal dari atap adalah Genting beton, rangka baja ringan, listplank gypsum, bubungan beton, plafond woodplank menggunakan list. Setelah dilakukan Rekayasa Nilai, diganti dengan Genting tanah liat karang pilang trenggalek, reng / usuk meranti, kuda-kuda meranti, listplank meranti, bumbungan karang pilang, plafond triplek menggunakan list. Biaya desain awal pada pekerjaan ini sebesar Rp 20,179,567.70 kemudian setelah dilakukan Rekayasa nilai menjadi $\mathrm{Rp} \operatorname{Rp}$ 17,816,120.90 jadi memperoleh penghematan biaya sebesar Rp 2,363,446.80 untuk pekerjaan atap ini.

2. Pada desain awal, pekerjaan rumah tipe $70 / 135$ tersebut memerlukan biaya sebesar Rp 106,147,912.98. Setelah dilakukan Rekayasa Nilai diperoleh penghematan biaya sebesar Rp 5,111,090.36 atau sebesar 0.048\%. Dengan demikian, pekerjaan rumah setelah dilakukan Rekayasa Nilai memerlukan biaya sebesar Rp 101,036,822.62 lebih rendah dibandingkan desain awal.

\subsection{Saran}

Setelah melihat hasil dari studi Rekayasa Nilai tersebut, maka penulis menyarankan :

1. Perlu membentuk team Rekayasa Nilai, karena setelah dilakukan analisa Rekayasa Nilai terdapat beberapa sub pekerjaan yang mengalami penurunan biaya pekerjaan.

2. Dalam merencanakan suatu pekerjaan konstruksi bangunan dibutuhkan beberapa perbandingan desain alternatif sehingga didapatkan perencanaan yang paling ekonomis.

3. Dalam pengambilan keputusan hasil Rekayasa Nilai yang akan diterapkan, dilakukan berdasarkan pertimbangan biaya hasil Rekayasa Nilai secara keseluruhan juga dengan mempertimbangkan faktor - faktor lain di luar sisi biaya.

\section{DAFTAR PUSTAKA}


Mochamad Tamim Ma'ruf. 2017. Rekayasa Nilai Harga Pembuatan Terhadap Efektifitas Penggunaan Bahan Pada Pembangunan Perumahan Tirto Penataran Asri Tipe 70/135 Kecamatan Nglegok Kabupaten Blitar. Jurnal Qua Teknika, (2017), 7(1) : 43 52

[1] Anonim. "Jurnal Value Engineering”. 24 Juli 2016. 17:17 WIB. http://ejournal.uajy.ac.id/446/3/2MTS01363.pdf

[2] Ayudya S P, Nurcahyo C B. "Penerapan Rekayasa Nilai pada Proyek Pembangunan Gedung Pendidikan Politeknik Elektronika Negeri Surabaya”. Fakultas Teknik Sipil dan Perencanaan Institut Teknologi Sepuluh Nopember. Surabaya. http://digilib.its.ac.id/public/ITS-paper-33337-3109100031-Paper.pdf

[3] Barie, Donald S. 1995. Manajemen Konstruksi Profesional Edisi II. Jakarta.

[4] Dipohusodo, I. 1999. Struktur Beton Bertulang Berdasarkan SK SNI TDepartemen Pekerjaan Umum, Kanisius, Yogyakarta.

[5] Johanson, J. 2003. Penerapan Value Engineering Pada Pelaksanaan Proyek Gudang Rotan di Kecamatan Balong Bendo Sidoarjo. Jurusan Teknik Sipil Institut Teknologi Nasional. Malang.

[6] Rumintang, Anna. 2008. "ANALISA REKAYASA NILAI PEKERJAAN STRUKTUR GEDUNG TEKNIK INFORMATIKA U P N "VETERAN" JATIM" . Skripsi. UPN "Veteran" Jawa Timur.

[7] Sabrang, H. 1995. Rekayasa Nilai. Universitas Trisakti. Jakarta.

[8] Soedrajat S. Analisa Anggaran Biaya Pelaksanaan : Penerbit "NOVA".

[9] Suryo, A. P. 2008. Penerapan Rekayasa Nilai (VE) Struktur Utama pada Pembangunan gedung Rawat Inap RS. Perkebunan Jember. Skripsi. Institut Teknologi Nasional. Malang. [10] Wulfram, I. E. 2002-2003. Manajemen Proyek Konstruksi. Andi. Yogyakarta. [11] -------. 2007. Cara Cepat menghitung Biaya Bangunan. Andi. Yogyakarta. 